\title{
Lokális szirolimuszterápia sikeres alkalmazása facialis angiofibromák kezelésére Bourneville-Pringle-kórban szenvedő gyermekeken
}

\author{
Bottyán Krisztina dr. ${ }^{1}$ - Kemény Lajos dr. ${ }^{1,2}$ - Csoma Zsanett Renáta dr. ${ }^{1}$ \\ ${ }^{1}$ Szegedi Tudományegyetem, Általános Orvostudományi Kar, Szent-Györgyi Albert Klinikai Központ, \\ Bőrgyógyászati és Allergológiai Klinika, Szeged \\ ${ }^{2}$ MTA-Szegedi Tudományegyetem, Általános Orvostudományi Kar, Szent-Györgyi Albert Klinikai Központ, \\ Dermatológiai Kutatócsoport, Szeged
}

\begin{abstract}
A facialis angiofibroma a Bourneville-Pringle-kór (sclerosis tuberosa) igen karakterisztikus bőrtünete, egyben egyik major diagnosztikus kritériuma is. Az arc centrális részére lokalizálódó hamartomatosus növedékek gyermekkorban alakulnak ki, majd az életkor előrehaladtával progrediálnak, és a beteg számára jelentős kozmetológiai problémát okoznak, a kezelőorvos számára pedig terápiás kihívást jelentenek. A tradicionális, invazív kezelési eljárások mellett új, ígéretes kezelési lehetőség a lokálisan alkalmazott szirolimusz. Az új terápiás lehetőségről számos nemzetközi közlemény született az utóbbi években, azonban egységes ajánlás az optimális szirolimuszkoncentrációra és -összetételre vonatkozólag nem áll rendelkezésre. A szerzők két, Bourneville-Pringle-kór miatt gondozott gyermek esetét mutatják be, akiknél sikeresen alkalmaztak lokális szirolimuszterápiát.

Orv Hetil. 2019; 160(13): 516-520.
\end{abstract}

Kulcsszavak: adenoma sebaceum, angiofibroma, szirolimusz, Bourneville-Pringle-kór, mTOR

\section{Successful treatment of facial angiofibromas with local sirolimus in childhood in Bourneville-Pringle disease}

Facial angiofibroma is the characteristic symptom and also a major diagnostic criterion for Bourneville-Pringle disease. The centrofacially localized hamartomatous tumours start to appear in early childhood, and progress over time. Facial angiofibromas represent a significant cosmetological problem for the patients and a therapeutic challenge for the physician. Beside the traditional invasive treating methods, topical sirolimus is a new, promising and well-tolerated treatment modality. Several studies and case reports have been published on this new therapeutic approach, but recommendation for the optimal sirolimus concentration still does not exist. We report here two cases when children were successfully treated with topical sirolimus.

Keywords: adenoma sebaceum, angiofibroma, sirolimus, Bourneville-Pringle disease, mTOR

Bottyán K, Kemény L, Csoma ZsR. [Successful treatment of facial angiofibromas with local sirolimus in childhood in Bourneville-Pringle disease]. Orv Hetil. 2019; 160(13): 516-520.

(Beérkezett: 2018. június 8.; elfogadva: 2018. október 17.)

\section{Rövidítések}

$\mathrm{CT}=($ computed tomography) számítógépes tomográfia; MR = mágneses rezonancia; $\mathrm{mTOR}=$ mammalian target of rapamycin; OGYÉI = Országos Gyógyszerészeti és Élelmiszeregészségügyi Intézet; PDL $=$ (pulsed dye laser) pulzáló festéklézer; TSC = (tuberous sclerosis complex $)$ sclerosis tuberosa
A sclerosis tuberosa (TSC) több szervrendszert érintő ritka, autoszomális dominánsan öröklődő genodermatosis, amelynek következtében hamartomák alakulhatnak ki az agyban (corticalis göbök, subependymalis nodulusok, subependymalis óriás sejtes astrocytomák), a szívben (rhabdomyoma), a vesében (angiomyolipoma), a 
tüdőben (lymphangioleiomyomatosis) és a bőrben (1. táblázat). A betegség előfordulási gyakorisága l a 12 000-hez [1], a neurofibromatosis után ez a leggyakoribb neurocutan szindróma [2]. A kórképnek számos elnevezése ismert, sclerosis tuberosa complex, fibroadenomatosis, epiloia, Bourneville-Pringle-betegség, Pringle-kór.

A kórkép autoszomális domináns módon öröklődik, vagy spontán sporadikus mutáció következménye, kialakulásáért a hamartin és tuberin fehérjéket kódoló TSC1 (9q32-34) és TSC2 (16pl3.3) tumorszuppresszor génekben kialakuló mutációknak van szerepük. A TSCfunkció károsodásával a mTOR- (mammalian target of rapamycin) útvonal felszabadul a gátlás alól, és sejtproliferáció indul be, mely hamartomatosus növedékek kialakulásában manifesztálódik.

A bőrgyógyászati tünetek igen gyakoriak és jellegzetesek, emellett a lokalizációból és korai megjelenésükból adódóan ezen eltérések kelthetik fel először a gyanút a TSC diagnózisának irányában. A betegek több mint 90\%ában jelentkezik egy vagy több bőrtünet, melyek már a korai életszakaszban manifesztálódnak [3]. A bőrtünetek megjelenése jellegzetes időbeli mintázatot mutat. A legkorábban a hipopigmentált maculák $(90 \%)$ jelennek meg, az esetek 90\%-ában az első életévben. Alakjuk legtöbbször szabálytalan, de jellegzetesek a törzsön a lándzsahegy formájú, úgynevezett „kőrislevél” foltok, illetve a végtagokon a sürün egymás mellett elhelyezkedő, apró, depigmentált laesiók, amelyeket „konfetti”foltoknak nevezünk [4]. A betegek 30\%-ában jelentkezik 'café-au lait' folt az élet első hónapjaiban. A második életévtől megjelenő, a törzsre lokalizálódó és jellegzetesen a sacralis régióban kialakuló bőrtünet az úgynevezett 'shagreen' folt, melyet egyenetlen felszíne és megjelenése miatt „malacbőrtünetnek” vagy „narancsbőrtünetnek” is neveznek (az elváltozás kötőszöveti naevus, és a betegek közel 50\%-ában alakul ki). Négyéves kortól kezdődően észleljük a kéz- és lábujjakon a periungualis fibromák (30$40 \%$ ), úgynevezett Koenen-tumorok kialakulását, melyek lassan nőnek, és akár a köröm teljes destrukcióját is okozhatják. Általában ötéves kort követően alakul ki a jellegzetes elhelyezkedése miatt „Pringle-pillangónak” is nevezett adenoma sebaceum (50\%), mely szövettanilag angiofibromának felel meg. Az orcák és az áll területén szimmetrikusan elhelyezkedő laesiók általában eruptívan jelennek meg, a kor előrehaladtával progressziót mutatnak, barnásvörös papulák, majd plakkok figyelhetők meg a betegeken; a lokalizáció következtében ez a kórkép leginkább stigmatizáló bőrtünete. Míg gyermekkorban a vascularis komponens, felnőttkorban egyre inkább a fibroticus komponens dominál a laesiókban, és a bőrtünet "stabilizálódik". Bizonyos esetekben az angiofibroma a homlok területén jellegzetes barnássárga színezetü, fibroticus plakként is jelentkezhet $[4,5]$. A facialis angiofibromák kezelése igen nagy kihívást jelent: a tradicionális fizikai kezelési formák (sebészeti eltávolítás, dermabrasio, lézeres kezelés) mellett ígéretes terápiás módszer a mTOR-gátló szirolimusz helyi alkalmazása.

\section{Esetek}

Első betegünknél, egy 14 éves leánygyermeknél születése óta ismert a mentális retardáció. Ötéves korában kezelték az arcon növekvő adenoma sebaceum, illetve ismétlődő, absence jellegü epileptiform rosszullétek miatt. A klinikai kép alapján a gyermekorvosban felmerült a TSC iránydiagnózisa, emiatt részletes kivizsgálás történt. A koponya-CT-n kétoldali, periventricularisan elhelyezkedő, 5-18 mm átmérőjű mészképletek kerültek leírásra. A hasi ultrahangvizsgálat a vesékben corticalis cysták, illetve a bal vesében angiomyolipoma fennállását mutatta. Szemészeti, kardiológiai eltérés nem igazolódott. Genetikai vizsgálat történt, mely durva szám- és szerkezetbeli eltérést nem igazolt.

Második betegünknél, egy 13 éves fiúgyermeknél kisdedkor óta ismert a mentális retardáció. 2 hónapos korától jelentkeztek testszerte hipopigmentált maculák, 3 hónapos korától pedig négy végtagi görcsrohammal járó rosszullétek. A Gyermekgyógyászati Klinikán neurológiai kivizsgálása megtörtént, epilepszia igazolódott, emiatt antikonvulzív terápia került beállításra. A klinikai kép alapján felmerült TSC iránydiagnózis miatt részletes kivizsgálás történt. A szemészeti vizsgálat opticus glioma, a koponya-MR-vizsgálat intracerebralis subependymalis nodulusok, illetve hamartomák jelenlétét igazolta. A további képalkotó vizsgálatok a vesében cysták, a szívben pedig rhabdomyoma jelenlétét írták le. Néhány évvel később bőrgyógyászati ambulanciánkon vizsgáltuk a kézés lábujjakon növekvő, periungualis angiofibromák miatt. A genetikai vizsgálat a TSC2-gén defektusát támasztotta alá.

Mindkét gyermeknél jelentős kozmetológiai panaszt okoztak az orcákon lévő, folyamatosan progrediáló facialis angiofibromák. Korábban lokális béta-blokkoló (timololgél) alkalmazása történt, illetve a fiúgyermeknél néhány nagyobb fibroma sebészeti eltávolítására került sor. Mivel az alkalmazott kezelések mellett számottevő javulást nem tapasztaltunk, lézerkezelés mellett döntöttünk. A szóba jövő modalitások az Er-Yag, Nd:Yag, illetve a pulzáló festéklézer (PDL) voltak; a terápia célkitűzése az adenomák ablatiója és az erythema kezelése volt. A kezelés limitációja, hogy a PDL az ismétlődő villanások miatt epilepsziás rohamot provokálhat, emiatt a szemeket minden kezelés alkalmával gondosan letakartuk. Az ablatív lézerterápia esetében a fájdalom gyakran kifejezett. 2017. március és szeptember között összesen 3 alkalommal részesültek a betegek PDL-, egy alkalommal pedig Nd:Yag-lézer-kezelésben. A gyermekek a kezelést jól tolerálták, epileptiform rosszullét nem jelentkezett, számottevő javulást a bőrtumorok kapcsán azonban nem észleltünk.

2017 tavaszán lokális szirolimuszkezelés bevezetése mellett döntöttünk, ennek céljából egyedi méltányossági kérelmet nyújtottunk be. A hazai forgalomban lévő, 0,1\%-os szirolimuszoldatból gyapjúviaszalkohol-tartalmú vehiculummal 0,05\%-os kenőcsöt készítettünk, me- 
lyet a betegek napi egy alkalommal alkalmazták, lefekvés előtt. Egy hónap elteltével az erythema mérséklődött, az eruptiók ellaposodtak, három hónap elteltével a tumorok jelentős fokú regresszióját tapasztaltuk. A kezelés során mellékhatás nem jelentkezett (1. és 2. ábra).

\section{Következtetések}

A facialis angiofibroma az arc centrális részén bilaterálisan elhelyezkedő, jellegzetesen a nasolabialis redők területét is involváló számos, apró erythemás papula, illetve nagyobb plakkok összessége. Kezelésére nemcsak az életminőséget rontó és stigmatizáló jellege miatt van szükség, hanem mert az esztétikai problémán túl kisebb traumát követően potenciálisan vérzésforrást jelenthet,
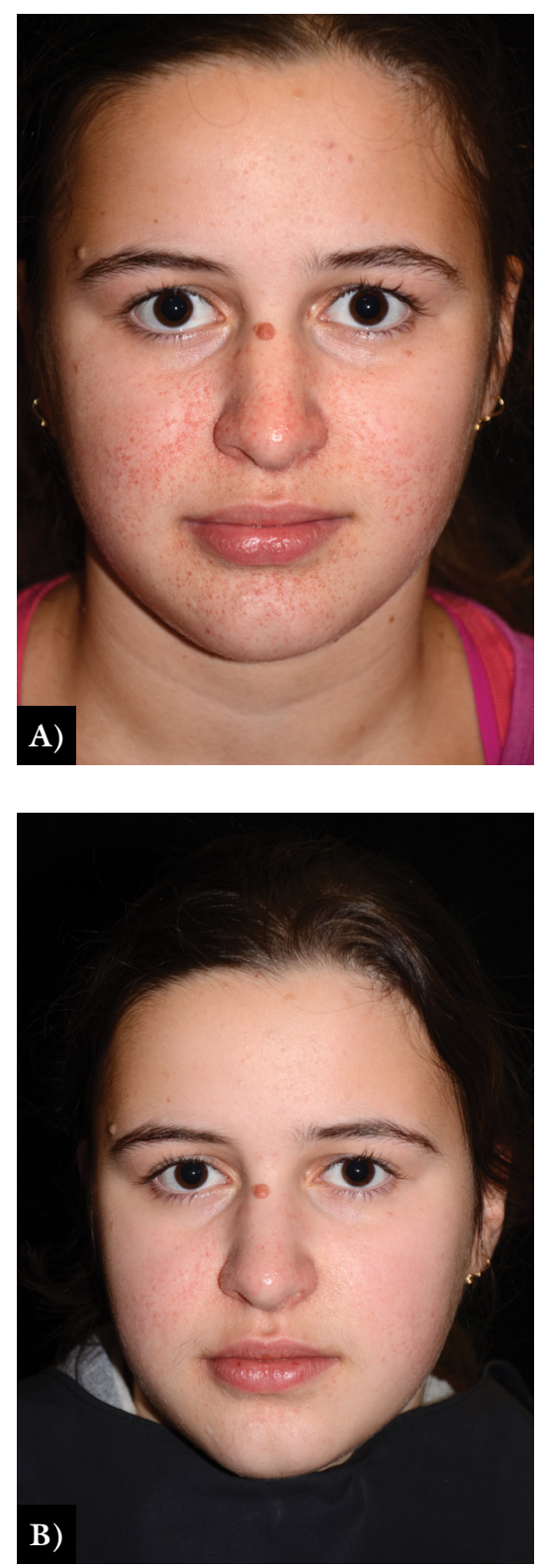

1. ábra

Lokális szirolimuszkezelés alkalmazása 14 éves leánygyermeknél. A beteg arcán lévő tumorok (A) jelentős fokú regressziója észlelhető, az erythema mérséklődik 3 hónap (B) múlva illetve növekedése révén akár nasalis obstrukciót is okozhat. A terápiás lehetőségek közé tartozik a dermabrasio, a nagyobb laesiók sebészi excisiója, illetve elektrokauteres eltávolítása. Dermabrasio során a nagyobb angiofibromákat 'shave' technikával távolítják el, majd a további képletek abrasiós kezelésére altatásos érzéstelenítés mellett kerül sor. A lapos, erythemás laesiók kezelésében (vascularis komponens miatt) a PDL, míg az előemelkedő angiofibromák esetében az ablatív lézerek alkalmazása lehetséges; a lézeres kezelés hatékonysága természetesen változó [6]. A felsorolt invazív kezelési formák lehetséges alternatívája a mTOR-kaszkád gátlásán keresztül ható lokális szirolimusz.

A szirolimusz a mTOR-inhibitorok csoportjába tartozó molekula, melyet gyógyszerkibocsátó stentek készíté-
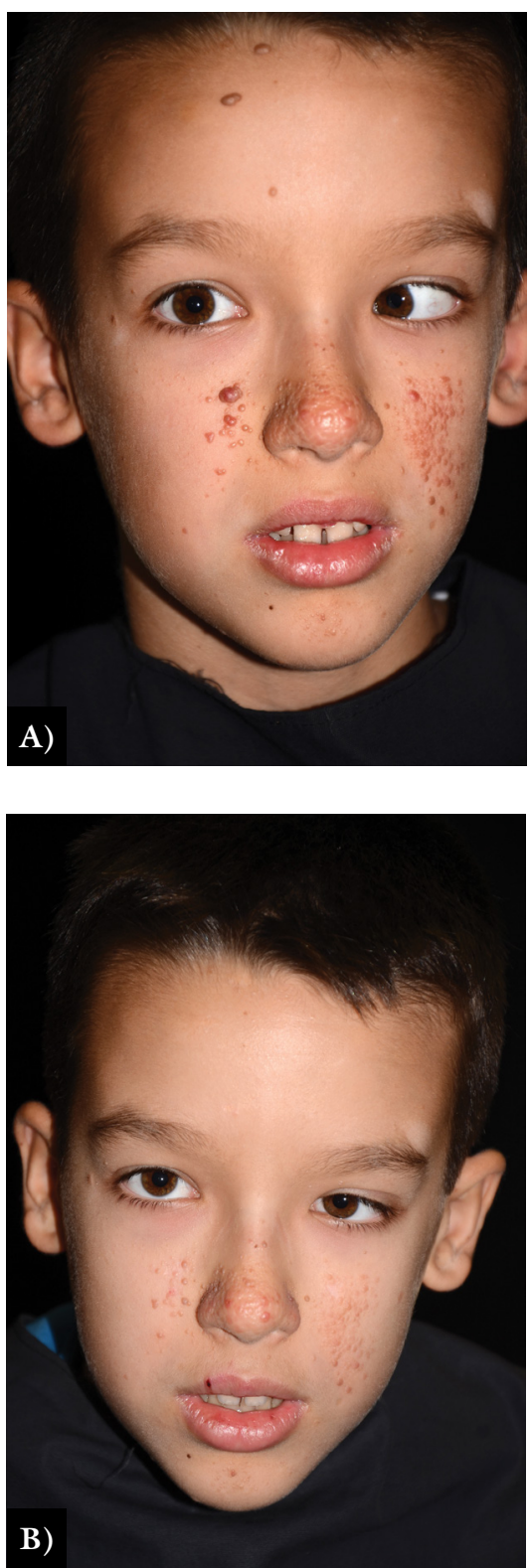

2. ábra

Lokális szirolimuszkenőss alkalmazása 13 éves fiúgyermeknél. Az erythema mértéke, a tumorok száma (A) szignifikánsan csökkent a kezelés hatására $(\mathrm{B})$ 
| A sclerosis tuberosa major és minor diagnosztikus kritériumai

\begin{tabular}{|c|c|}
\hline Major kritériumok & Minor kritériumok \\
\hline $\begin{array}{l}\text { 1. Hypomelanoticus foltok } \\
(>3, \min .5 \mathrm{~mm})\end{array}$ & 1. „Konfetti”bőrtünet \\
\hline 2. Angiofibromák (>3) & 2. Fogzománcárkok (>3) \\
\hline 3. Periungualis fibromák (>2) & 3. Intraoralis fibromák (>2) \\
\hline 4. 'Shagreen' folt & 4. Retinalis akromatikus folt \\
\hline $\begin{array}{l}\text { 5. Multiplex retinalis } \\
\text { hamartoma }\end{array}$ & 5. Multiplex vesecysták \\
\hline 6. Corticalis dysplasia & 6. Nem renalis hamartomák \\
\hline 7. Subependymalis csomók & \\
\hline $\begin{array}{l}\text { 8. Subependymalis óriás sejtes } \\
\text { astrocytoma }\end{array}$ & \\
\hline 9. Cardialis rhabdomyoma & \\
\hline 10. Lymphangioleiomyomatosis & \\
\hline 11. Angiomyolipomák (>2) & \\
\hline
\end{tabular}

séhez, illetve vesetranszplantáción átesett betegeknél a szervkilökődés megelőzése céljából alkalmaznak. Immunszuppresszív hatását a T-sejtek sejtciklusának gátlása révén fejti ki, tumorellenes hatását pedig a mTOR-kaszkád gátlásával: ennek során antiproliferatív és angiogenezist gátló hatásai érvényesülnek [7]. A szirolimusz facialis angiofibromákra gyakorolt kedvező hatását először Bourneville-Pringle-kór miatt gondozott, vesetranszplantáción átesett és emiatt orális szirolimuszterápiában részesülő betegeknél tapasztalták [8], ahol a kezelés ideje alatt a facialis angiofibroma regressziót mutatott. A szirolimusz a mellékhatásprofiljából adódóan csak olyan betegeknek adható szisztémásan, akiknél a belszervi érintettség ezt indokolja, emiatt merült fel az igény lokális gyógyszerkészítmény alkalmazására. Mivel jelenleg sem Magyarországon, sem külföldön nincs kereskedelmi forgalomban szirolimusztartalmú helyi készítmény, a vizsgálatok során szirolimusztabletta (Rapamune 0,5 $\mathrm{mg}$, $1 \mathrm{mg}, 2 \mathrm{mg}$ ) porításával, illetve szirolimusz belsőleges oldat (Rapamune $1 \mathrm{mg} / \mathrm{ml}$ oldat) felhasználásával készítettek különböző koncentrációjú externákat. 2010ben Haemel és mtsai publikálták az első esetriportot, melyben szirolimusztabletta porításával készített 1\%-os kenőcsöt alkalmaztak napi rendszerességgel. Három hónap elteltével mind az erythema, mind a papulák méretének csökkenését tapasztalták [9]. Az utóbbi közlemény megjelenése óta két randomizált, kontrollált klinikai vizsgálat, illetve számtalan esetriport jelent meg. A vizsgálatokban az externák vivőanyagának, a szirolimusznak a koncentrációja $(0,03 \%-1 \%)$, az alkalmazás gyakorisága, illetve a kezelés időtartama is különbözött. A vizsgálatokban a készítményt a leggyakrabban kenőcs formájában alkalmazták. Egyes esetekben a szirolimusz belsőleges oldatot emollienssel történő elegyítés nélkül használták, ilyenkor azonban gyakrabban jelentkezett lokális irritáció [10]. A lokális szirolimusz kedvező esztétikai eredményt mutatott mind a facialis angiofibromák, mind a hypomelanoticus maculák esetében, minimális szisztémás hatóanyag-abszorpció mellett. 2017-ben egy randomizált, placebokontrollált klinikai vizsgálat ( 18 felnőtt, illetve 18 gyermek beteget vizsgáltak) igazolta, hogy felnőtteknél a 0,2\%-os, gyermekeknél pedig már a 0,05\%-os koncentráció is hatékony; 3 hónap elteltével a laesiók kevésbé voltak előemelkedőek, számukban és méretükben regresszió volt megfigyelhető, illetve az erythema is mérséklődött [11]. Néhány fiatalkorú betegnél, ahol a tünetek nem voltak kiterjedtek, közel komplett remissziót sikerült elérni [12].

Feltehetően az angiofibromák fokozatos, fibroticus átalakulásával magyarázható a tapasztalat, hogy gyermekekben gyorsabb, kedvezőbb klinikai válasz alakul ki, mint felnőttekben, és jobb eredményt várhatunk azokban az esetekben, amelyekben a börtüneten belül az erythemás komponens dominál a fibroticus komponenssel szemben. Mellékhatásprofilja igen kedvező, használata biztonságos, a szérumban a szirolimuszszint megemelkedése nem detektálható [13]. A kezelés hátrányaként említendő annak magas költsége, illetve az a tény, hogy a lokális szirolimuszterápia felfüggesztését követően a laesiók gyakran recidiválnak. Magyarországon sclerosis tuberosában indikáción túli gyógyszeralkalmazás miatt a használata OGYÉI-engedélyhez kötött.

A facialis angiofibroma a TSC karakterisztikus, stigmatizáló bőrtünete, amely a kor előrehaladtával progressziót mutat, majd felnőttkorban stabilizálódik. A szakirodalmi adatok és saját tapasztalataink alapján a lokális szirolimuszterápia hatékony és biztonságos kezelési módozat a facialis angiofibromák kezelésére. Közleményünkben Magyarországon elsóként számolunk be a szirolimuszkenőcs sclerosis tuberosában történő sikeres alkalmazásáról gyermekekben. Természetesen a lokális szirolimusz koncentrációjának és dozírozásának optimalizálásához további, nagyobb betegpopuláción végzett vizsgálatok szükségesek.

Anyagi támogatás: A közlemény az „Intelligens élettudományi technológiák, módszertanok, alkalmazások fejlesztése és innovatív folyamatok, szolgáltatások kialakítása a szegedi tudásbázisra építve" címú, EFOP-3.6.1-162016-00008-as azonosítóval rendelkezó pályázaton belül a „Multidiszciplináris egészségügyi, egészségnevelési és egészségfejlesztési összefogás az egészséges gyermekvállalásért és az egészséges gyermekek megszületéséért a Dél-alföldi Régióban” alprojekt támogatásával jött létre.

Szerzői munkamegosztás: B. K.: A vizsgálat koncepciójának kidolgozása, a betegek kezelése, a betegek adatainak feldolgozása, az irodalmi adatok áttekintése, a kézirat megírása. K. L.: A kézirat átolvasása, bírálata, javítása. Cs. Zs. R.: A vizsgálat koncepciójának kidolgozása, a be- 
tegek kezelése, a kézirat átolvasása, bírálata, javítása. A cikk végleges változatát valamennyi szerző elolvasta és jóváhagyta.

Érdekeltségek: A szerzőknek nincsenek érdekeltségeik.

\section{Köszönetnyilvánítás}

Dr. Csoma Zsanett Renáta a Magyar Tudományos Akadémia Bolya János Kutatási Ösztöndíjában részesült (2015-2018).

\section{Irodalom}

[1] Umeoka S, Koyama T, Miki Y, et al. Pictorial review of tuberous sclerosis in various organs. Radiographics 2008; 28 : e32.

[2] Hurst JS, Wilcoski S. Recognizing an index case of tuberous sclerosis. Am Fam Physician 2000; 61: 703-708, 710.

[3] Cardis MA, DeKlotz CM. Cutaneous manifestations of tuberous sclerosis complex and the paediatrician's role. Arch Dis Child. 2017; 102: 858-863.

[4] Jóźwiak S, Schwartz RA, Janniger CK, et al. Skin lesions in children with tuberous sclerosis complex: their prevalence, natural course, and diagnostic significance. Int J Dermatol. 1998; 37: 911-917.

[5] Hurwitz S, Braverman IM. White spots in tuberous sclerosis. J Pediatr. 1970; 77: 587-594.

[6] Papadavid E, Markey A, Bellaney G, et al. Carbon dioxide and pulsed dye laser treatment of angiofibromas in 29 patients with tuberous sclerosis. Br J Dermatol. 2002; 147: 337-342.
[7] Dabora SL, Franz DN, Ashwal S, et al. Multicenter phase 2 trial of sirolimus for tuberous sclerosis: kidney angiomyolipomas and other tumors regress and VEGF-D levels decrease. PLOS ONE 2011; 6: e23379.

[8] Hofbauer GF, Marcollo-Pini A, Corsenca A, et al. The mTOR inhibitor rapamycin significantly improves facial angiofibroma lesions in a patient with tuberous sclerosis. Br J Dermatol. 2008; 159: $473-475$.

[9] Haemel AK, O'Brian AL, Teng JM. Topical rapamycin: a novel approach to facial angiofibromas in tuberous sclerosis. Arch Dermatol. 2010; 146: 715-718.

[10] Foster RS, Bint LJ, Halbert AR. Topical 0.1\% rapamycin for angiofibromas in paediatric patients with tuberous sclerosis: a pilot study of four patients. Aust J Dermatol. 2012; 53: 52-56.

[11] Wataya-Kaneda M, Nakamura A, Tanaka M, et al. Efficacy and safety of topical sirolimus therapy for facial angiofibromas in the tuberous sclerosis complex: a randomized clinical trial. JAMA Dermatol. 2017; 153: 39-48.

[12] Tu J, Foster RS, Bint LJ, et al. Topical rapamycin for angiofibromas in paediatric patients with tuberous sclerosis: follow up of a pilot study and promising future directions. Australas J Dermatol. 2014; 55: 63-69.

[13] Teng JM, Cowen EW, Wataya-Kaneda M, et al. Dermatologic and dental aspects of the 2012 International Tuberous Sclerosis Complex Consensus Statements. JAMA Dermatol. 2014; 150: 1095-1101.

(Csoma Zsanett Renáta dr., Szeged, Korányi fasor 6., 6720 e-mail: csoma.zsanett@med.u-szeged.hu)

\section{A rendezvények és kongresszusok híranyagának leadása}

a lap megjelenése előtt legalább 40 nappal lehetséges, a 6 hetes nyomdai átfutás miatt. Kérjük megrendelőink szíves megértését.

A híranyagokat a következő címre kérjük: Orvosi Hetilap titkársága: edit.budai@akademiai.hu Akadémiai Kiadó Zrt.

A cikk a Creative Commons Attribution 4.0 International License (https://creativecommons.org/licenses/by/4.0/) feltételei szerint publikált Open Access közlemény, melynek szellemében a cikk bármilyen médiumban szabadon felhasználható, megosztható és újraközölhető, feltéve, hogy az eredeti szerző és a közlés helye, illetve a CC License linkje és az esetlegesen végrehajtott módosítások feltüntetésre kerülnek. (SID_1) 